\title{
AKTYWNA POLITYKA SPOŁECZNA WOBEC OSÓB ZAGROŻONYCH WYKLUCZENIEM SPOŁECZNYM (NA PRZYKŁADZIE WOJEWÓDZTWA WARMIŃSKO-MAZURSKIEGO)
}

\section{ACTIVE SOCIAL POLICY TOWARDS PEOPLE AT RISK OF SOCIAL EXCLUSION (BASED ON THE EXAMPLE OF WARMIA AND MASURIA PROVINCE)}

\author{
Elżbieta Subocz ${ }^{1(\mathrm{~B}, \mathrm{C}, \mathrm{D}, \mathrm{E}, \mathrm{F})}$
}

${ }^{1}$ Katedra Socjologii, Wydział Nauk Społecznych, Uniwersytet Warmińsko-Mazurski w Olsztynie

Subocz E. (2017), Aktywna polityka społeczna wobec osób zagrożonych wykluczeniem społecznym (na przykładzie województwa warmińsko-mazurskiego). Rozprawy Społeczne, 11(3), s. 35-43.

Wkład autorów:

A. Zaplanowanie badań

B. Zebranie danych

C. Dane - analiza i statystyki

D. Interpretacja danych

E. Przygotowanie artykułu

F. Wyszukiwanie i analiza

literatury

G. Zebranie funduszy
Tabele: 1

Ryciny: 2

Literatura: 27

Otrzymano: 30.03.2017

Zaakceptowano: 13.04.2017

\begin{abstract}
Streszczenie
Celem artykułu jest charakterystyka działalności samorządu województwa warmińsko-mazurskiego podejmowanej w ramach aktywnej polityki społecznej na rzecz osób zagrożonych wykluczeniem społecznym. W oparciu o dostępne dane statystyczne przedstawiono działania z zakresu reintegracji społeczno-zawodowej realizowane przez centra i kluby integracji społecznej oraz spółdzielnie socjalne. Artykuł jest próbą odpowiedzi na pytanie, jaka jest efektywność tych działań mierzona wskaźnikiem odsetka osób usamodzielnionych ekonomicznie? Dane statystyczne pokazują, iż aktywność podmiotów zatrudnienia socjalnego przynosi efekty, lecz nie są one wielkie.
\end{abstract}

Słowa kluczowe: aktywna polityka społeczna, centra integracji społecznej, kluby integracji społecznej, spółdzielnie socjalne

\section{Summary}

The aim of the article is to characterize the activities undertaken by the provincial government of Warmia and Masuria within the framework of active social policy for the benefit of people at risk of social exclusion. Basing on the available statistics, the article presents some activities in the field of social and professional reintegration which were carried out in social integration centres, clubs, and social cooperatives. It attempts to show how effective these actions are when measured by the index of people's economic independence. The statistics show that the institutional activities into social employment bring results, although they are not impressive.

Keywords: active social policy, social integration centres, social integration clubs, social cooperatives

\section{Wstęp}

Aktywna polityka społeczna (APS) zwana inaczej „polityką aktywizacji” lub „polityką aktywizującą” to koncepcja dynamicznie rozwijająca się w Europie od połowy lat 90. XX wieku (Rymsza 2003; Karwacki, Rymsza 2011). Stanowi odpowiedź na kryzys idei welfare states postrzeganej jako przestarzałej w obliczu nowych wyzwań (Szarfenberg 2009), jakie wiążą się z poszukiwaniem nowatorskich rozwiązań dla „starych” problemów społecznych, jak bezrobocie czy ubóstwo.

APS to koncepcja wielowymiarowa, obejmująca różne dziedziny polityki społecznej. W swoich założeniach zakłada m.in.: 1) orientację na usługi aktywizujące beneficjentów, kosztem świadczeń osłonowych, 2) integrację publicznych służb społecznych oraz służb zatrudnienia, 3) indywidualiza- cję usług aktywizujących, 4) upowszechnianie tzw. środowiskowej metody pracy socjalnej polegającej na aktywizowaniu całych społeczności, 5) wzrost znaczenia organizacji pozarządowych w świadczeniu różnych usług, 6) łączenie prawa do wsparcia socjalnego z obowiązkiem pracy (Karwacki, Rymsza 2011).

W literaturze przedmiotu APS jest definiowana jako: „alternatywa dla „pasywnych” transferów socjalnych, mającym na celu zapewnienie wszystkim obywatelom bezpieczeństwa socjalnego i dobrobytu niezależnie od ich aktywności ekonomicznej na rynku. Na aktywną politykę społeczną składają się programy i działania, które w swych założeniach mają aktywizować różne grupy niesamodzielnych życiowo beneficjentów, kształtując w nich umiejętności zawodowe, ucząc kompetencji społecznych; słowem wyrabiać zaradność życiową" (Rymsza 2013, s.143).

\footnotetext{
Adres korespondencyjny: Elżbieta Subocz, Katedra Socjologii Wydziału Nauk Społecznych Uniwersytetu Warmińsko-Mazurskiego w Olsztynie, ul. Szrajbera 11, 10-007 Olsztyn, e-mail: elzbieta.subocz@uwm.edu.pl, tel.: 895338390 Copyright by: Państwowa Szkoła Wyższa im. Papieża Jana Pawła II w Białej Podlaskiej, Elżbieta Subocz

Czasopismo Open Access, wszystkie artykuły udostępniane są na mocy licencji Creative Commons Uznanie autorstwa-użycie niekomercyjne-na tych samych warunkach 4.0 Międzynarodowe (CC BY-NC-SA 4.0, http://creativecommons.org/licenses/by-nc-sa/4.0/).
} 
Owe programy obejmują dwa rodzaje przedsięwzięć: 1) działania z zakresu reintegracji społecznej i zawodowej, traktowane jako usługi społeczne o charakterze przedzatrudnieniowym, 2) działania prozatrudnieniowe na otwartym i chronionym rynku pracy (Karwacki i in. 2014). Inicjatywy z zakresu reintegracji społeczno-zawodowej na rzecz osób zagrożonych wykluczeniem społecznym prowadzą przede wszystkim w Polsce centra i kluby integracji społecznej nazywane podmiotami zatrudnienia socjalnego. Natomiast działania prozatrudnieniowe są charakterystyczne dla przedsiębiorstw społecznych, które funkcjonuja głównie w formie spółdzielni socjalnych.

Wykluczenie społeczne definiuję tutaj jako brak możliwości pełnego uczestnictwa jednostek w podstawowych sferach życia społecznego, tj. rynku pracy, edukacji, zdrowia, kultury, wypoczynku. Przeciwieństwem jest inkluzja społeczna, czyli proces włączania jednostek w aktywne uczestnictwo w życiu społecznym. Kategorie osób zagrożonych wykluczeniem społecznym zostały wymienione w art. 1 pkt. 2 Ustawy o zatrudnieniu socjalnym i należą do nich: bezdomni realizujący indywidualny program wychodzenia z bezdomności, uzależnieni od alkoholu i narkotyków po zakończonym programie psychoterapii/terapeutycznym, chorzy psychicznie, długotrwale bezrobotni, zwalniani z zakładów karnych, uchodźcy, osoby niepełnosprawne.

Przystąpienie Polski do Unii Europejskiej znacznie przyspieszyło proces przeorientowania polityki społecznej z pasywnej na aktywną. W latach 20032006 przyjęto kilka regulacji prawnych, dzięki którym stworzono prawnoinstytucjonalne ramy do prowadzenia działań aktywizujących, a jednocześnie zapewniono na ten cel środki finansowe, głównie w ramach Europejskiego Funduszu Społecznego (EFS). Wśród pakietu aktów prawnych należy wymienić: Ustawę o działalności pożytku publicznego i o wolontariacie (wprowadzoną w życie w roku 2003), Ustawę o zatrudnieniu socjalnym (2003), Ustawe o promocji zatrudnienia i instytucjach rynku pracy (2004), Ustawę o pomocy społecznej (2004) oraz Ustawę o spółdzielniach socjalnych (2006) (Rymsza 2013).

Prowadzone $\mathrm{w}$ ramach APS działania aktywizujące są często jedyną szansą na usamodzielnienie beneficjentów długotrwale korzystających ze wsparcia socjalnego państwa. Jest to szczególnie ważne w przypadku osób/społeczności zamieszkujących spauperyzowane, cechujące się wysoką stopą bezrobocia regiony. Pomoc społeczna w postaci świadczeń socjalnych okazuje się bowiem mało efektywna i zamiast usamodzielniać świadczeniobiorców, niejednokrotnie uzależnia ich od otrzymywanego wsparcia.

Celem artykułu jest charakterystyka działań samorządu województwa warmińsko-mazurskiego na rzecz osób zagrożonych wykluczeniem społecznym. Region Warmii i Mazur to obszar, który od wielu lat szczególnie dotknięty jest takimi problemami spo- łecznymi, jak bezrobocie i ubóstwo. Z tego względu w latach 2005-2008 w województwie wdrożono aktywną politykę społeczną. Instytucje pomocy społecznej wprowadziły aktywne formy wsparcia jednostek zagrożonych ekskluzją społeczną. W oparciu o dostępne dane statystyczne, w tekście przedstawiono aktywność podstawowych instytucji, które na terenie województwa realizują działania z zakresu reintegracji społeczno-zawodowej, tj. centrów i klubów integracji społecznej oraz spółdzielni socjalnych. Artykuł jest próbą odpowiedzi na pytanie, jaka jest efektywność działalności wymienionych podmiotów mierzona wskaźnikiem odsetka osób usamodzielnionych ekonomicznie?

\section{Główne problemy społeczne województwa warmińsko-mazurskiego}

Jednym z najważniejszych problemów społecznych cechujących województwo warmińsko-mazurskie jest najwyższy od lat w kraju wskaźnik bezrobocia. Nie bez znaczenia pozostaje fakt, iż obszar regionu obejmuje swoim zasięgiem tereny byłych PGR-ów, które stanowią około $1 / 3$ powierzchni województwa. W grudniu 2016 r. stopa bezrobocia rejestrowanego w województwie warmińsko-mazurskim ukształtowała się na poziomie 14,2\% i była najwyższa w kraju (średnia dla kraju wyniosła 8,3\%). Do powiatów o najwyższej stopie bezrobocia należały: braniewski (25,2\%), bartoszycki (23,7\%), kętrzyński (23,7\%). Najniższą stopę bezrobocia zanotowano w stolicy Warmii i Mazur - Olsztynie (5,1\%). Bezrobotni będący w szczególnej sytuacji na rynku pracy w końcu grudnia 2016 r. stanowili aż 86,4\% ogółu bezrobotnych. Do tej kategorii osób zaliczani są m.in.: długotrwale bezrobotni, których udział w liczbie zarejestrowanych ogółem wyniósł 56,7\%; osoby powyżej 50 roku życia $(28,8 \%)$ osoby niepełnosprawne $(6,5 \%)$ oraz młodzi bezrobotni do 25 roku (13,5\%) (Komunikat o sytuacji...2017). Wypada też dodać, iż od wielu lat struktura bezrobocia na warmińsko-mazurskim rynku pracy charakteryzuje się przewagą kobiet. Na koniec 2015 r. kobiety stanowiły $52,8 \%$ ogółu bezrobotnych. W równie trudnym położeniu znajdowały się osoby zamieszkałe na wsi, które stanowiły połowę $(50,9 \%)$ osób zarejestrowanych w urzędach pracy. Wspomnieć należy również o osobach legitymujących się niższym poziomem wykształcenia, którzy najgorzej radzą sobie na rynku pracy. Na koniec 2015 r. osoby z wykształceniem gimnazjalnym i niższym oraz zawodowym miały największy udział wśród ogółu bezrobotnych - odpowiednio: 33,5\% i 27,4\% (Regionalny plan działań... 2016). Wymienione wyżej kategorie osób szczególnie narażone są na ryzyko zagrożenia wykluczeniem społecznym i to do nich przede wszystkim kierowane są różne programy oraz inicjatywy z zakresu inkluzji społecznej realizowane na terenie Warmii i Mazur.

Sytuacja na lokalnym rynku pracy jest dosyć trudna. Wartość współczynnika aktywności zawodowej mieszkańców województwa warmińsko-mazurskie- 
go jest najniższa w skali kraju. W III kwartale 2015 r wskaźnik ten wyniósł 52,8\% (w Polsce 56,4\%). Podobne tendencje kształtują się w obszarze wartości wskaźnikazatrudnienia. Na koniec III kwartału $2015 \mathrm{r}$. w regionie Warmii i Mazur ukształtował się on na poziomie $48,4 \%$, podczas gdy średnia dla kraju wyniosła w tym okresie $52,4 \%$. W porównaniu z latami 2014-2015 można jednak zaobserwować, iż dystans między wartościami dla kraju i regionu zmniejsza się (tamże).

Konsekwencją wysokiej stopy bezrobocia jest pauperyzacja mieszkańców regionu. Obszar Warmii i Mazur to od lat jeden $\mathrm{z}$ najbiedniejszych regionów Polski. Według danych GUS (2015), stopa ubóstwa skrajnego na terenie województwa, za granicę którego przyjęto minimum egzystencji, w roku 2014 wyniosła 14,8\% i była dwukrotnie wyższa niż średnia dla kraju - 7,4\%.

Wskaźnikiem skali ubóstwa jest odsetek osób korzystających ze wsparcia instytucji pomocy społecznej w stosunku do ogółu mieszkańców regionu. Z danych Regionalnego Ośrodka Polityki Społecznej - ROPS (2015) wynika, iż w 2014 r. w województwie warmińsko-mazurskim (bez względu na rodzaj, formę oraz źródło finansowania) świadczeniami z tytułu pomocy społecznej (zarówno w ramach ustawowych zadań własnych, jak i zleconych) realizowanymi przez ośrodki pomocy społecznej i powiatowe centra pomocy rodzinie objęto 76.675 rodzin, a w tych rodzinach 198.666 osób. W skali całego województwa stanowi to $13,7 \%$ mieszkańców. Powiatami o najwyższym procencie ludności objętej pomocą społeczną w stosunku do ogółu mieszkańców powiatu były: powiat kętrzyński - 25,0\% (16.265 osób), powiat elbląski - 18,7\% (10.911 osób), powiat szczycieński - 18,0\% (12.760 osób), powiat bartoszycki - 17,8\% (10.683 osoby) oraz powiat nowomiejski - 17,5\% (7.752 osoby). Najniższy procent ludności objętej pomocą społeczną w stosunku do ogółu mieszkańców odnotowano w mieście Olsztyn - 5,7\% (9.976 osób), oraz w mieście Elbląg - 9,0\% (11.1000 osób). Najczęstszymi przyczynami udzielania pomocy społecznej było: bezrobocie $(9,1 \%$ ludności województwa), ubóstwo $(7,6 \%)$ oraz niepełnosprawność $(3,5 \%)$.

Wymienione problemy nie wyczerpuja oczywiście katalogu problemów społecznych występujących w regionie Warmii i Mazur, ale sa to najważniejsze kwestie socjalne znajdujące się w centrum zainteresowań władz samorządu województwa.

\section{Polityka społeczna w dokumentach strategicznych Warmii i Mazur}

Formy, działania i metody realizacji regionalnej polityki społecznej na rzecz osób zagrożonych ekskluzją społeczną, zostały zawarte w wielu dokumentach strategicznych województwa warmińsko-mazurskiego. Są to przede wszystkim (Subocz 2015):

1. Strategia Polityki Społecznej Województwa Warmińsko-Mazurskiego do 2020 roku. Główny cel strategii skoncentrowano wokół osób i rodzin mieszkających na terenie województwa, ich środowisk lokalnych i otoczenia instytucjonalnego, współdziałających ze sobą i zaangażowanych we wzmacnianie integracji oraz aktywizacji społecznej i zawodowej (Strategia polityki społecznej...2011).

2. Polityka Senioralna Województwa Warmińsko-Mazurskiego na lata 2014-2020. Za najważniejszy obszar działań uznano: zdrowie seniorów, zwiększenie liczby osób starszych korzystających z usług podtrzymujących zdrowie oraz dostępnej infrastruktury i usług socjalnych, zwiększenie aktywności zawodowej seniorów oraz wzrost aktywności seniorów w obszarze turystyki, sportu i rekreacji (Polityka Senioralna... 2013).

3. Wojewódzki Program Profilaktyki i Rozwiązywania Problemów Alkoholowych w Województwie Warmińsko-Mazurskim na lata 2012-2015, którego celem głównym jest szersze zintegrowanie i wzmacnianie działań na rzecz profilaktyki i rozwiązywania problemów alkoholowych w województwie (Wojewódzki Program Profilaktyki 2012).

4. Wojewódzki Program Przeciwdziałania Narkomanii na lata 2013-2017, który za cel główny stawia sobie ograniczenie zjawiska narkomanii w województwie warmińsko-mazurskim (Wojewódzki Program Przeciwdziałania Narkomanii" 2012).

5. Wojewódzki program wyrównywania szans i przeciwdziałania wykluczeniu społecznemu oraz pomocy w realizacji zadań na rzecz zatrudniania osób niepełnosprawnych na lata 2012 2015. Celem strategicznym programu jest aktywne uczestnictwo osób niepełnosprawnych w życiu rodzinnym, społecznym i zawodowym oraz ich integracja ze środowiskiem lokalnym (Wojewódzki program wyrównywania ... 2011).

6. Wojewódzki Program Polityki Prorodzinnej na lata 2012-2016. Głównym celem realizacji tego programu jest ekonomicznie, społecznie i kulturowo silniejsza oraz bardziej wydolna w pełnieniu funkcji opiekuńczo-wychowawczych rodzina (Wojewódzki Program Polityki Prorodzinnej... 2012).

7. Wojewódzki Program Rozwoju Ekonomii Społecznej Warmia i Mazury 2015-2020, który za cel główny stawia sobie zwiększenie udziału ekonomii społecznej w rozwoju społeczno-gospodarczym województwa ze szczególnym uwzględnieniem aktywizacji zawodowej i społecznej grup zagrożonych wykluczeniem (Wojewódzki Program Rozwoju Ekonomii... 2015).

Instrumentami kreowania lokalnej polityki społecznej w poszczególnych gminach i powiatach są gminne/powiatowe strategie rozwiazywania problemów społecznych, które umożliwiają identyfikację najważniejszych problemów społecznych danych gmin/powiatów oraz wytyczają kierunki, propozycje 
działań rozwiązywania tych problemów przy zaangażowaniu i współpracy różnych instytucji publicznych i organizacji społecznych.

\section{Wybrane podmioty realizujące aktywną politykę społeczną wobec osób zagrożonych wykluczeniem społecznym i efekty tych działań}

\section{Centra Integracji Społecznej (CIS)}

Podstawą prawną działalności centrów i klubów integracji społecznej jest Ustawa o zatrudnieniu socjalnym z dnia 13 czerwca 2003 r. Zgodnie z art. 2 ustawy celem działalności tych placówek jest reintegracja społeczna osób zagrożonych wykluczeniem społecznym prowadzona równolegle $\mathrm{z}$ reintegracją zawodową. Powyższe cele są realizowane poprzez:

a) kształcenie umiejętności pozwalających na pełnienie ról społecznych,

b) nabywanie umiejętności zawodowych oraz przyuczenie do zawodu, przekwalifikowanie lub podwyższanie kwalifikacji zawodowych,

c) naukę planowania życia i zaspokajania potrzeb własnym staraniem,

d) naukę umiejętności racjonalnego gospodarowania posiadanymi środkami pieniężnymi (art. 3 ustawy).
Szczegółowe kwestie dotyczące zasad tworzenia i organizacji CIS reguluje wspomniana wcześniej ustawa. W 2015 r. w województwie warmińsko-mazurskim funkcjonowało 7 CIS-ów, prowadzonych głównie przez organizacje pozarządowe. Ich działalność w dużej mierze jest finansowana ze środków publicznych (budżetu samorządu województwa, budżetów gmin oraz Funduszu Pracy). Placówki te mogą się starać o dofinansowanie swoich projektów także ze środków unijnych, a dalsze ich funkcjonowanie może być finansowane $\mathrm{z}$ prowadzonej działalności handlowej, usługowej lub wytwórczej. CIS w Olsztynie, który jest jedna z pierwszych tego typu placówek zarejestrowanych w Polsce, postrzegane jest jako wzorcowa placówka realizująca „(...) przemyślany i sprawdzony w działaniu zbiór metod i procedur wzmacniania klientów jako uczestników życia społecznego" (Karwacki i in. 2014, s. 245-246).

Na koniec czerwca 2013 r. w Polsce funkcjonowały 124 centra i 197 klubów integracji społecznej (NIK 2013). Liczbe placówek na przestrzeni lat w województwie warmińsko-mazurskim przedstawia poniższa tabela.

Tabela 1. Liczba centrów i klubów integracji społecznej w województwie warmińsko-mazurskim w latach 2005-2015

\begin{tabular}{|c|c|c|c|c|c|c|c|c|c|c|c|}
\hline Rok & $\mathbf{2 0 0 5}$ & $\mathbf{2 0 0 6}$ & $\mathbf{2 0 0 7}$ & $\mathbf{2 0 0 8}$ & $\mathbf{2 0 0 9}$ & $\mathbf{2 0 1 0}$ & $\mathbf{2 0 1 1}$ & $\mathbf{2 0 1 2}$ & $\mathbf{2 0 1 3}$ & $\mathbf{2 0 1 4}$ & $\mathbf{2 0 1 5}$ \\
\hline Liczba CIS & 2 & 4 & 4 & 4 & 3 & 4 & 4 & 6 & 6 & 7 & 7 \\
\hline Liczba KIS & 50 & $--^{*}$ & 67 & --- & --- & 61 & 58 & 57 & 52 & 47 & 32 \\
\hline
\end{tabular}

* brak danych

Źródło: opracowanie własne na podstawie danych ROPS z Olsztyna.

Z danych statystycznych wynika (zob. rycina 1), iż na przestrzeni lat 2007-2014 zaobserwować można było wzrost liczby uczestników zajęć w CIS-ach ogółem, jak również osób, które rozpoczęły oraz zakończyły zajęcia, zaś w 2015 r. nastąpił spadek tego trendu. Ów wzrost był związany z pojawieniem się nowych tego rodzaju placówek w różnych częściach regionu Warmii i Mazur oraz wzrostem zainteresowania uczestnictwem w zajęciach. Wskaźnik osób usamodzielnionych ekonomicznie $\mathrm{w}$ stosunku do osób, które pomyślnie ukończyły zajęcia wahał się w granicach $50 \%$ w roku 2007; $40 \%-41 \%$ w latach 2012-2013, 33\% w roku 2014 i 41\% w roku 2015. Najniższa wartość osiagnał w roku 2009 - 28\%. $\mathrm{Na}$ przestrzeni lat 2009-2014 odnotować można zmniejszanie się odsetka osób, które po ukończonym procesie aktywizacji społeczno-zawodowej w CIS usamodzielniły się ekonomicznie.

W 2015 r. liczba osób uczestniczących w zajęciach zmniejszyła się (o 13\%) w stosunku do 2014 r., kiedy to w zajęciach CIS-ów uczestniczyło najwięcej osób od początku funkcjonowania tych placówek. Wzrosła natomiast liczba osób usamodzielnionych ekonomicznie (w 2015 r. w stosunku do 2014 r. o 15\%). Wśród absolwentów CIS usamodzielnionych ekonomicznie największą grupę stanowiły osoby, które zostały zatrudnione u pracodawcy bez zatrudnienia wspieranego - 94 osoby (co stanowi około 78\% osób usamodzielnionych) (ROPS 2016).

Uczestnikami zajeć w zakresie reintegracji społeczno-zawodowej w CIS-ach funkcjonujących w województwie warmińsko-mazurskim są przede wszystkim osoby długotrwale bezrobotne, legitymujące się głównie wykształceniem podstawowym i gimnazjalnym oraz zawodowym. Wśród uczestników przeważaja osoby powyżej 45 roku życia oraz wieku 25-35 lat. Kończąc proces reintegracji społeczno-zawodowej uczestnicy zajęć uzyskują tytuł absolwenta, co pozwala niektórym z nich skorzystać ze środków Funduszu Pracy na rozpoczęcie własnej działalności gospodarczej lub działalności w formie spółdzielni socjalnej (tamże). 


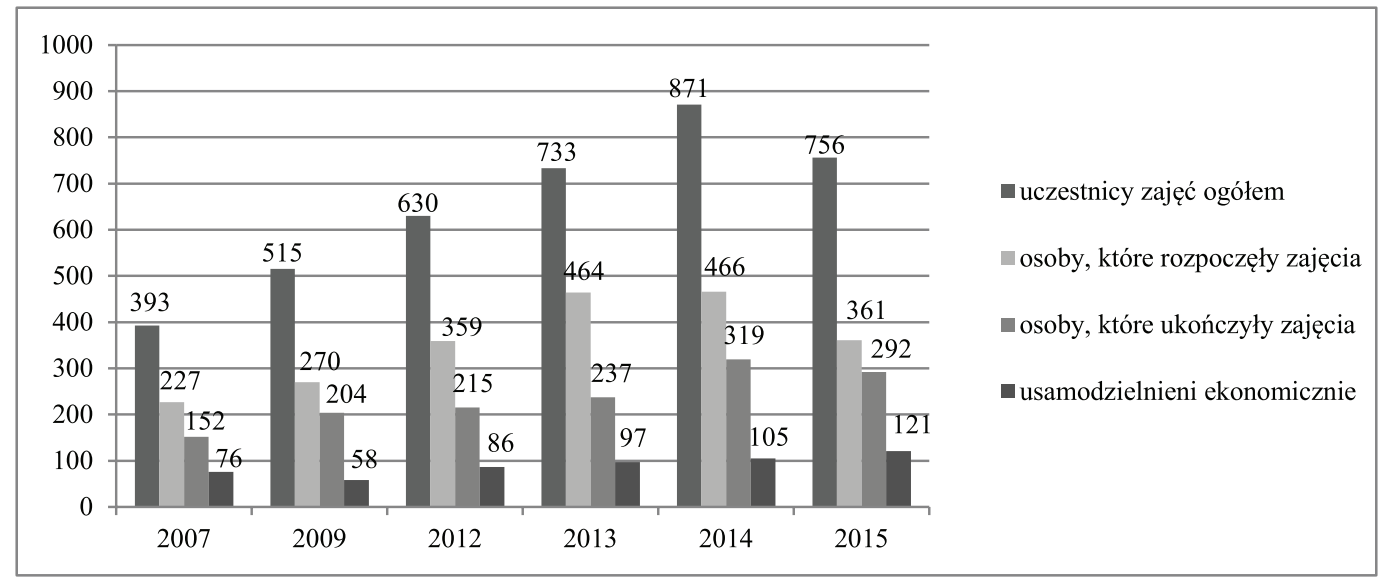

Rycina 1. Liczba uczestników zajęć w centrach integracji społecznej w województwie warmińsko-mazurskim w latach 2007-2015 Źródło: ROPS 2016.

Z danych Regionalnego Ośrodka Polityki Społecznej (ROPS 2016) wynika, iż w 2015 r., osobom uczestniczącym w zajęciach, oferowano m.in. następujące usługi:

- uczestnictwo w grupach samopomocowych lub grupach wsparcia (udział wzięło 430 osób),

- indywidualne konsultacje z psychologiem i terapeutą (408 osób),

- zajęcia edukacyjne (450 osób),

- szkolenia zawodowe (338 osób),

- praktyki i staże zawodowe (487 osób),

- zajęcia z zakresu prowadzenia własnej działalności gospodarczej lub spółdzielni socjalnej (127 osób).

\section{Kluby Integracji Społecznej (KIS)}

Zgodnie z art. 18 Ustawy o zatrudnieniu socjalnym, w KIS-ach można organizować: działania, które mają na celu pomoc w znalezieniu pracy oraz przygotowanie do podjęcia zatrudnienia lub podjęcia działalności w formie spółdzielni socjalnej, prace społecznie użyteczne, roboty publiczne, poradnictwo prawne, działalność samopomocową $\mathrm{w}$ zakresie zatrudnienia, spraw mieszkaniowych i socjalnych oraz staże, o których mowa w przepisach o promocji zatrudnienia i instytucjach rynku pracy.
Klub integracji społecznej może być prowadzony przez gminę lub jednostkę organizacyjną gminy, organizację pozarządową lub kościelną, spółdzielnię socjalną. W województwie warmińsko-mazurskim KIS-y funkcjonują zwykle w strukturze ośrodka pomocy społecznej. Od 2012 r. placówki te mogą rozpocząć swoją działalność po dokonaniu wpisu do rejestru wojewody. Liczbę klubów na przestrzeni lat przedstawia tabela 1.

Z danych ROPS (2016) wynika, iż najwięcej KIS-ów na terenie Warmii i Mazur funkcjonowało w roku 2007, w kolejnych latach zaobserwować można zmniejszanie się ilości placówek. W 2015 r. liczba klubów była najniższa od początku ich funkcjonowania, co związane było z zakończeniem przez ośrodki pomocy społecznej realizacji projektów finansowanych z Programu Operacyjnego Kapitał Ludzki (PO $\mathrm{KL}$ ) na lata 2007-2013. Najwięcej zarejestrowanych KIS-ów działa w powiecie olsztyńskim (8) i w powiecie nidzickim (4). W pięciu powiatach nie ma tego typu placówek (gołdapskim, węgorzewskim, giżyckim, bartoszyckim i ostródzkim). KIS-y utrzymują się głównie z dotacji gminnych oraz środków unijnych. Liczbę uczestników zajęć w klubach na przestrzeni lat przedstawia poniższa rycina.

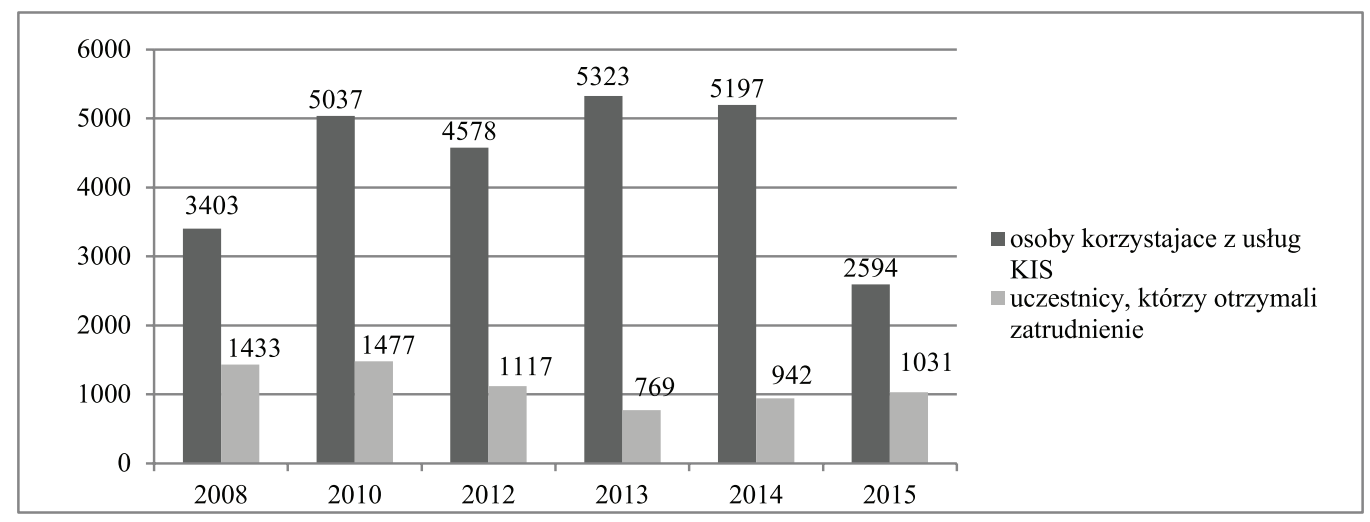

Rycina 2. Liczba uczestników zajęć w klubach integracji społecznej w województwie warmińsko-mazurskim w latach 20082015. Dane za lata 2012-2015 obejmują liczbę uczestników w KIS-ach zarejestrowanych i niezarejestrowanych ogółem. Źródło: ROPS 2016. 
Z danych przedstawionych na rycinie wynika, iż liczba osób ogółem korzystających z usług KIS-ów na przestrzeni lat była zmienna, najniższą odnotowano w roku 2015, najwyższą zaś w roku 2013. Wskaźnik osób, które otrzymały zatrudnienie w stosunku do osób korzystających z usług klubów wahał się w granicach od 42\% w roku 2008 do 18\% w roku 2014 Najniższą wartość osiągnął w roku 2013 - 14\%. W 2015 r. w porównaniu z 2014 r. wzrosła liczba osób, które otrzymały zatrudnienie o niemalże 9\%.

Wśród uczestników zajęć w KIS-ach przeważają osoby długotrwale bezrobotne legitymujące się wykształceniem podstawowym. Ponieważ kluby są zwykle prowadzone przez ośrodki pomocy społecznej, uczestnikami zajęć są zwykle beneficjenci świadczeń z tytułu pomocy społecznej kierowani do klubów przez pracowników socjalnych. KIS-y oferują swoim uczestnikom m.in.:

- kursy (np. zawodowe, komputerowe, prawa jazdy, językowe), staże, praktyki zawodowe, wizyty studyjne,

- szkolenia z zakresu zakładania własnej działalności gospodarczej, funkcjonowania spółdzielni socjalnej,

- pomoc w poszukiwaniu pracy, w tym kierowanie do prac społecznie użytecznych lub robót publicznych,

- różnego rodzaju warsztaty: umiejętności i kompetencji społecznych, umiejętności wychowawczych, aktywizacji zawodowej, edukacji prawnej, ekonomii społecznej, z zakresu poszukiwania pracy, przedsiębiorczości,

- doradztwo prawne, psychologiczne i zawodowe,

- diagnozę osobowości uczestników, badanie ich preferencji zawodowych (ROPS 2016).

W 2015 r. dziewięć klubów integracji społecznej dodatkowo realizowało Program Aktywizacji i Integracji (PAI), którym objęto ogółem 164 osoby. Celem programu jest kompleksowe wsparcie osób bezrobotnych korzystających ze świadczeń pomocy społecznej, dla których ustalono trzeci profil pomocy. To innowacyjne narzędzie wprowadzone nowelizacją z dnia 27 maja 2014 r., Ustawy o promocji zatrudnienia i instytucjach rynku pracy, jest połączeniem prac społecznie użytecznych stanowiących element integracji zawodowej z intensywną integracją społeczną. Narzędzie to ma służyć wzmocnieniu kompetencji i postaw niezbędnych do prawidłowego funkcjonowania beneficjentów w społeczeństwie i zapobiegać ich trwałemu wykluczeniu społecznemu (tamże)

Absolwenci zajęć w KIS-ach mogą skorzystać z dwóch ścieżek usamodzielnienia ekonomicznego. Pierwsza związana jest z powrotem na otwarty rynek pracy - absolwent ma szansę podjąć zatrudnienie u pracodawcy lub rozpocząć własną działalność gospodarczą, w tym w formie spółdzielni socjalnej. Druga ścieżka to zatrudnienie wspierane - absolwent może być skierowany do prac społecznie użytecznych, robót publicznych lub na staż. Z danych ROPS (2016) wynika, iż w 2015 r. zatrudnienie, zgodnie z wyżej wymienionymi ścieżkami usamodzielnienia ekonomicznego, podjęło 1031 osób, w tym:
728 osób wykonywało prace społecznie użyteczne, 15 osób wykonywało prace interwencyjne,

- 46 osób zostało skierowanych na roboty publiczne, 8 osób zostało skierowanych do CIS,

- 3 osoby uzyskały zatrudnienie w spółdzielni socjalnej,

3 osoby podjęły działalność gospodarczą,

- 164 osoby podjęły zatrudnienie u pracodawcy,

- 64 osoby uzyskały zatrudnienie w innej formie (np. staż).

Z przedstawionych wyżej danych wynika, iż najbardziej popularną formą usamodzielnienia ekonomicznego są prace społecznie użyteczne. Mimo, iż jest to doraźna forma zatrudnienia, jest ważna z kilku powodów. Absolwenci zajęć w klubach wracają na rynek pracy, uczą się odpowiedzialności i systematyczności; czują się potrzebni w społeczeństwie, co niewątpliwie podnosi ich samoocenę. Wykonywana praca pozwala też na uzyskiwanie niewielkich dochodów finansowych.

\section{Spółdzielnie socjalne}

Podstawą prawną funkcjonowania spółdzielni socjalnych jest Ustawa z dnia 27 kwietnia 2006 roku o spółdzielniach socjalnych, która reguluje kwestie dotyczące zakładania i prowadzenia tych podmiotów ekonomii społecznej. Zgodnie z art. 2 przedmiotowej ustawy, spółdzielnia socjalna jest rodzajem przedsiębiorstwa społecznego prowadzonego w oparciu o prace osobistą osób w niej zatrudnionych i podobnie jak kluby oraz centra integracji społecznej działa na rzecz społecznej i zawodowej reintegracji swoich członków. Spółdzielnia może też prowadzić działalność społeczną i oświatowo-kulturalną na rzecz swoich członków i społeczności lokalnej oraz działalność społecznie użyteczną w sferze zadań publicznych określonych $w$ Ustawie z dnia 24 kwietnia 2003r. o działalności pożytku publicznego i o wolontariacie. Zysk wypracowany $\mathrm{z}$ działalności gospodarczej, która ma zwykle charakter wytwórczy, handlowy lub usługowy, ma służyć przede wszystkim społeczno-zawodowym celom reintegracji członków spółdzielni socjalnej.

W wyniku wsparcia dotacyjnego dla spółdzielni socjalnych $w$ ramach Poddziałania 7.2.2 PO KL na lata 2007-2013, łącznie w województwie warmińsko-mazurskim w tym okresie powstały 52 spółdzielnie socjalne. Było to również efektem szeroko zakrojonych działań instytucji wspierających ekonomię społeczną, jak również kampanii informacyjno-promocyjnych. W roku 2014 powstało kolejnych 20 nowych spółdzielni socjalnych, zaś w 2015 roku - jedynie 4 nowe podmioty, co wiąże się z wyczerpaniem środków finansowych w ramach dotacji dla spółdzielni socjalnych (spółdzielnie korzystały głównie ze środków Funduszu Pracy). Na dzień 31 grudnia 2015 r. aktywnie funkcjonowało 77 spółdzielni socjalnych (Raport o stanie ekonomii społecznej... 2016). Warto w tym miejscu dodać, iż w województwie warmińsko-mazurskim funkcjonuje wyjątkowy w skali kraju 
instytucjonalny system wsparcia podmiotów ekonomii społecznej, który tworzą m.in.: 4 ośrodki wsparcia ekonomii społecznej, 3 podmioty pełniące rolę operatorów wsparcia finansowego, 10 inkubatorów przedsiębiorczości społecznej, centra organizacji pozarządowych połączonych w sieć obejmującą 9 powiatów, 14 lokalnych grup działania. Instytucje te świadczą bezpłatne, kompleksowe usługi informacyjne, edukacyjne, animacyjne, promocyjne, doradcze, szkoleniowe, infrastrukturalne oraz wsparcie finansowe w formie pożyczek i poręczeń kredytowych.

Zdecydowana większość funkcjonujących spółdzielni liczy 5 członków. Zakres działalności spółdzielni socjalnych jest różnorodny i obejmuje m.in.: działalność gastronomiczna, prace porządkowe i remontowo-budowlane, opiekę nad dziećmi i osobami starszymi, działalność artystyczną, sprzedaż (w tym internetową), usługi krawieckie, tworzenie stron internetowych, usługi reklamowe i poligraficzne (tamże).

Rezultaty analiz Regionalnego Ośrodka Polityki Społecznej w Olsztynie w latach 2010-2011 na temat trwałości aktywizacji zawodowej członków spółdzielni socjalnych dowiodły, iż osoby, które pracowały w spółdzielniach (nawet w przypadku ich likwidacji) utrzymały aktywność na rynku pracy i nie powróciły do systemu pomocy społecznej. Brakuje jednak bardziej aktualnych danych statystycznych dotyczących dalszych losów członków (obecnych lub byłych) spółdzielni socjalnych.

\section{Podsumowanie}

Podsumowując, wypada zauważyć, iż w województwie warmińsko-mazurskim liczba CIS-ów uległa zwiększeniu od roku 2012, podczas gdy liczba KIS-ów systematycznie spada od 2010 roku. Przybywa natomiast spółdzielni socjalnych, co jest efektem dotacji udzielanych $\mathrm{w}$ ramach poddziałania 7.2.2 PO KL. Patrząc na mapę rozlokowania podmiotów zatrudnienia socjalnego można stwierdzić, iż północno-wschodnia ściana województwa jest bardziej uboższa w tego typu placówki (głównie powiaty: bartoszycki, węgorzewski, gołdapski) niż ściana zachodnia i centrum województwa. To stanowi wyzwanie dla służb społecznych, aby w tych rejonach województwa powoływać do życia tego rodzaju podmioty.

Na przestrzeni ostatnich lat zaobserwować można było wzrost ilości osób zagrożonych wykluczeniem społecznym poddawanych procesom aktywizacji społeczno-zawodowej zarówno w klubach, jak i centrach integracji społecznej. Trend ten załamał się w roku 2015, co było związane głównie z zakończeniem realizacji projektów finansowanych z EFS. Ze zwiększaniem się liczby uczestników zajęć nie wiązał się jednak wzrost liczby osób usamodzielnionych ekonomicznie, które ostatecznie ukończyły zajęcia w centrach i klubach integracji społecznej. Efektywność działalności podmiotów zatrudnienia socjalnego jest zatem relatywnie niska. Notuje się też przypadki upadłości spółdzielni socjalnych po 12 miesiącach działalności (czyli po okresie ochronnym dzięki publicznym dotacjom), a czasami też po dłuższym okresie ich funkcjonowania.

Na niską efektywność działań prowadzonych przez centra i kluby integracji społecznej zwróciła również uwagę Najwyższa Izba Kontroli w swym raporcie pokontrolnym (NIK 2013) ${ }^{1}$. Działalność wspomnianych placówek jako głównych filarów instytucji zatrudnienia socjalnego w Polsce jest oceniana przez NIK pozytywnie, mimo stwierdzonych nieprawidłowości dotyczących głównie organizacji skontrolowanych placówek i nieprzestrzegania obowiązujących procedur. Jednocześnie NIK zaobserwowała niezbyt wysoką skuteczność w realizacji zadań zatrudnienia socjalnego, mierzoną odsetkiem uczestników usamodzielnionych ekonomicznie w relacji do pozytywnie kończących zajęcia. Dla centrów wyniosła ona 38\%, a dla klubów $17 \%$. Relatywnie niska skuteczność w realizacji zadań zatrudnienia socjalnego sprawia, że jest to instytucja kosztowna. Jednostkowy koszt usamodzielnienia ekonomicznego uczestnika zajęć w skontrolowanych centrach wyniósł w latach 2011-2012 przeciętnie 69 tys. zł, zaś dla klubów integracji społecznej - 12 tys. zł. Jako jedną z głównych przyczyn niskiej efektywności działań centrów i klubów integracji społecznej w realizacji zadań zatrudnienia socjalnego wskazuje się brak rozwiniętej współpracy z lokalnymi partnerami w zakresie reintegracji zawodowej uczestników (głównie z powiatowymi urzędami pracy i lokalnymi przedsiębiorcami) oraz brak systematycznego monitoringu dalszych losów absolwentów. Tym samym placówki te nie posiadały pełnej informacji, która mogłaby służyć analizie i doskonaleniu sposobu wykonywania zadań w zakresie reintegracji społeczno-zawodowej. Przyczyn niezbyt wysokiej skuteczności działalności placówek NIK upatruje ponadto w rozwiązaniach prawnych, m.in. braku w zapisach Ustawy o zatrudnieniu socjalnym upoważnienia dla wojewody do kontroli tych instytucji w zakresie merytorycznej realizacji zadań zatrudnienia socjalnego.

Czy warto zatem podejmować bardzo trudne skądinąd wysiłki zmierzające do usamodzielniania osób o tzW. niskiej zatrudnialności? W literaturze przedmiotu nie brakuje głosów krytycznych odnoszących się do słabych stron działalności placówek zatrudnienia socjalnego mającej wpływ na jakość świadczonych usług (Karwacki 2009; Karwacki i in. 2014). Jeśli w wyniku takich działań usamodzielni się kilkanaście bądź kilkadziesiąt osób, to warto podejmować tego typu inicjatywy. Dzięki procesowi aktywizacji następuje przerwanie bierności zawodowej beneficjentów, ulokowanie ich chociaż na krótki czas na rynku pracy, co niewątpliwie ma wpływ na poczucie własnej wartości. Przede wszystkim zaś pozwala to osobom zagrożonym wykluczeniem społecznym na zdobywanie środków finansowych i zaprzestanie na pewien okres korzystania ze wsparcia socjalnego państwa.

Raport dotyczy kontroli przeprowadzonej w latach 2011-2013 w 29 placówkach w Polsce. Wśród kontrolowanych instytucji zatrudnienia socjalnego znajdowały się również te funkcjonujące w województwie warmińsko-mazurskim. 


\section{Literatura:}

1. Grewiński M., Karwacki A., Rymsza M. (2010), Nowa polityka społeczna - aktywizacja, wielosektorowość, współdecydowanie. Mazowieckie Centrum Polityki Społecznej, Warszawa.

2. GUS (2015), Ubóstwo ekonomiczne w Polsce w 2014 r. (na podstawie badania budżetów gospodarstw domowych). Warszawa, http://stat.gov.pl/obszary-tematyczne/warunki-zycia/ubostwo-opieka-spoleczna/ ubostwo-ekonomiczne-w-polsce-w-2014-r-,14,2.html, (data dostępu: 20.11.2016).

3. Karwacki A., Kaźmierczak T., Rymsza M. (2014), Reintegracja. Aktywna polityka społeczna w praktyce. Instytut Spraw Publicznych, Warszawa.

4. Karwacki A., Rymsza M. (2011), Meandry upowszechniania koncepcji aktywnej polityki społecznej w Polsce, W: M. Grewiński, M. Rymsza (red.), Polityka aktywizacji w Polsce. Usługi reintegracji w sektorze gospodarki społecznej. Wyższa Szkoła Pedagogiczna TWP w Warszawie, Warszawa, s. 29-54.

5. Karwacki A. (2009), Centra integracji społecznej, kluby integracji społecznej, zakłady aktywności zawodowej w świetle badań. Instytut Spraw Publicznych, Toruń, http://www.ekonomiaspoleczna.pl/files /ekonomiaspoleczna.pl/public/materialy_oss_ cis_polanowice/karwacki_badania_tekst.pdf, (data dostępu: 21.11.2016).

6. Komunikat o sytuacji społeczno-gospodarczej województwa warmińsko-mazurskiego w grudniu 2016 r., Urząd Statystyczny w Olsztynie, http://olsztyn.stat.gov.pl/opracowania-biezace/komunikaty-i-biuletyny/inne-opracowania/komunikat-o-sytuacji-spoleczno-gospodarczej-wojewodztwa-warminsko-mazurskiego-w-grudniu-2016-r-,3,50.html, (data dostępu: 22.02.2017).

7. NIK (2013), Zatrudnienie socjalne jako instrument działań na rzecz rozwiązywania trudnej sytuacji życiowej oraz wzmocnienia aktywności osób zagrożonych wykluczeniem społecznym. Informacja o wynikach kontroli, Warszawa, https://www.nik.gov.pl/plik/id,5728,vp,7421.pdf, (data dostępu: 24.02.2017).

8. Polityka Senioralna Województwa Warmińsko-Mazurskiego na lata 2014-2020 (2013), Olsztyn, http:// www.portal.warmia.mazury.pl/polityka-spoleczna/programy-i-projekty, (data dostępu: 22.11.2016).

9. Raport o stanie ekonomii społecznej $w$ województwie warmińsko-mazurskim w 2015r. Monitoring wdrażania wojewódzkiego programu rozwoju ekonomii społecznej Warmia i Mazury 2015-2020 - rok 2015, (2016), Olsztyn, http://portal.warmia.mazury.pl/polityka-spoleczna/ekonomia-spoleczna-na-warmii-i-mazurach, (data dostępu: 28.02.2017).

10. Regionalny Plan Działań na Rzecz Zatrudnienia na 2016 rok w województwie warmińsko-mazurskim, (2016), http://wupolsztyn.praca.gov.pl/-/2063247-regionalny-plan-dzialan-na-rzecz-zatrudnienia-na2016-rok, (data dostępu: 22.02.2017).

11. ROPS (2015), Analiza problemów społecznych województwa warmińsko-mazurskiego w ujęciu pomocy społecznej za rok 2014, Olsztyn, http://www.portal.warmia. mazury.pl/polityka-spoleczna/pomoc-i-integracja-spoleczna, (data dostępu: 11.11. 2016).

12. ROPS (2016), Informacja nt. centrów i klubów integracji społecznej funkcjonujących w województwie warmińsko-mazurskim wg stanu na dzień 31 grudnia 2015 r., Olsztyn, http://www.portal.warmia.mazury.pl/ polityka-spoleczna/pomoc-i-integracja-spoleczna, (data dostępu: 23.02.2017).

13. Rymsza M. (2013), Aktywizacja w polityce społecznej. W stronę rekonstrukcji europejskich welfare states? Instytut Filozofii i Socjologii PAN, Warszawa.

14. Rymsza M. (2003), Aktywna polityka społeczna w teorii i praktyce, W: T. Kaźmierczak, M. Rymsza (red.), W stronę aktywnej polityki społecznej. Instytut Spraw Publicznych, Warszawa, s. 19-32.

15. Strategia polityki społecznej województwa warmińsko-mazurskiego do 2020 roku (2012), Olsztyn, http:// bip.warmia.mazury.pl/ urzad_marszalkowski /510/Strategia_ polityki_spolecznej/, (data dostępu: 20.11.2016).

16. Subocz E. (2015), Polityka społeczna Samorządu Województwa Warmińsko-Mazurskiego wobec osób i rodzin zagrożonych wykluczeniem społecznym (w kontekście realizacji Priorytetu VII Programu Operacyjnego Kapitał Ludzki), W: B. Chrostowska, M. Dymowska, M. Zmysłowska (red.), Rodzina wobec problemów i wyzwań współczesności. W poszukiwaniu rozwiązań. T. 2, Wydawnictwo Uniwersytetu Warmińsko-Mazurskiego w Olsztynie, Olsztyn, s. 329-340.

17. Szarfenberg R. (2009), Rodzaje i formy aktywnej polityki społecznej, W: G. Firlit-Fesnak, M. Szylko-Skoczny (red.), Polityka społeczna. Podręcznik akademicki. Wydawnictwo Naukowe PWN, Warszawa, s. 401-413.

18. Ustawa z dnia 27 kwietnia 2006 r. o spółdzielniach socjalnych, Dz. U. 2006 r., nr 94, poz. 651 z późn. zm., http://isap.sejm.gov.pl/DetailsServlet?id=WDU20060940651, (data dostępu: 28.02.2017).

19. Ustawa z dnia 20 kwietnia 2004 r. o promocji zatrudnienia i instytucjach rynku pracy, Dz. U. 2004 r., nr 99 , poz. 1001 z późn. zm., http://isap.sejm.gov.pl/ Details Servlet? id=WDU20040991001, (data dostępu: 28.02.2017).

20. Ustawa z dnia 12 marca 2004 r. o pomocy społecznej, Dz. U. 2004 r., nr 64, poz. 593 z późn. zm., http://isap. sejm.gov.pl/DetailsServlet?id=WDU20040640593, (data dostępu: 28.02.2017).

21. Ustawa z dnia 13 czerwca 2003 r. o zatrudnieniu socjalnym, Dz. U. 2003 r. nr 122, poz. 1143 z późn. zm., http://isap.sejm.gov.pl/DetailsServlet?id=WDU20031221143, (data dostępu: 28.02.2017). 
22. Ustawa z dnia 24 kwietnia 2003 r. o działalności pożytku publicznego i o wolontariacie, Dz. U. 2003 r., nr 96, poz. 873 z późn. zm., http://isap.sejm.gov.pl/DetailsServlet?id=WDU20030960873, (data dostępu: 28.02. 2017).

23. Wojewódzki Program Polityki Prorodzinnej na lata 2012-2016 (2012), Olsztyn, http://www.portal.warmia.mazury.pl/polityka-spoleczna/programy-i-projekty? start=10, (data dostępu: 20.11.2016).

24. Wojewódzki Program Profilaktyki i Rozwiązywania Problemów Alkoholowych w Województwie Warmińsko-Mazurskim na lata 2012-2015 (2012), Olsztyn, http://www.portal.warmia.mazury.pl/polityka-spoleczna/programy-i-projekty, (data dostępu: 22.11.2016).

25. Wojewódzki Program Przeciwdziałania Narkomanii na lata 2013-2017 (2012), Olsztyn, http://www.portal.warmia.mazury.pl/polityka-spoleczna/programy-i-projekty (data dostępu: 23.11.2016).

26. Wojewódzki Program Rozwoju Ekonomii Społecznej Warmia i Mazury 2015-2020 (2015), Olsztyn, http:// www.portal.warmia.mazury.pl/polityka-spoleczna/programy-i-projekty, (data dostępu: 22.11.2016).

27. Wojewódzki program wyrównywania szans i przeciwdziałania wykluczeniu społecznemu oraz pomocy w realizacji zadań na rzecz zatrudniania osób niepełnosprawnych na lata 2012-2015 (2012), Olsztyn, http:// www.portal.warmia.mazury.pl/polityka-spoleczna/programy-i-projekty, (data dostępu: 22.11.2016). 